\title{
120 rocznica odkrycia promieni $X$ przez Wilhelma Conrada Röntgena w listopadzie 1895 roku
}

\author{
Richard F. Mould
}

Powodem napisania tego tekstu jest 120 rocznica odkrycia promieni X. Przedstawia on doświadczenia i obserwacje poczynione przez Röntgena w Würzburgu, które doprowadziły go do wiekopomnego odkrycia. Zawiera przykłady zdjęć wykonanych przez Röntgena, określonych w pierwszej pracy jako Eine Neue Art von Strahlen (zdjęcia te nie znalazły się w publikacji z 1896 roku, ale wysłano je do grona zaprzyjaźnionych fizyków z różnych zakątków świata). Przywołuje trzy prace Röntgena, jedyne, jakie kiedykolwiek napisał na temat promieniowania rentgenowskiego. Ukazały się też zaled wie dwa wywiady, w których Wilhelm Röntgen mówił, co myśli o swoim odkryciu. Pierwszy ukazał się w kwietniu 1896, a przeprowadził go amerykański dziennikarz HJW Dam z Magazine McClure; drugi przeprowadził w kwietniu 1898 roku brytyjski producent aparatury rentgenowskiej i czołowy członek Röntgen Society w Londynie Adolf Isenthal, który odwiedził Röntgena w imieniu Towarzystwa. Röntgen wygłosił także tylko jeden publiczny wykład na temat promieni X. Miał on miejsce 23 stycznia 1896 roku w Physikalisch-medizinischen Gesellschaft w Würzburgu.

\section{$120^{\text {th }}$ Anniversary of the Discovery of X-rays by Wilhelm Conrad Röntgen, November 1895}

This short review celebrates the discovery of X-rays 120 years ago. It describes the experiments and observations made by Röntgen in Würzburg, which led to the discovery; illustrates examples of Röntgen's radiographs which were referred to in his first paper \{they were not published in 1896 but were only supplied to some of his physicist colleagues throughout the world\} Eine Neue Art von Strahlen; and references the only three papers Röntgen ever wrote on X-rays. What Röntgen thought of his great discovery can be found from the only two interviews ever published: in April 1896 by the American journalist H J W Dam of McClure's Magazine; and in April 1898 by the British manufacturer of X-ray apparatus and a leading member of the Röntgen Society in London, Adolf Isenthal, who visited Röntgen on behalf of the Society. Röntgen only gave one public lecture. This was on 23 January 1896 at the Physikalisch-medizinischen Gesellschaft in Würzburg.

Słowa kluczowe: historia medycyny, promienie X, W.C. Röntgen

Key words: history of medicine, X-rays, WC Röntgen

\section{Wstęp}

Wilhelm Conrad Röntgen urodził się 27 marca $1845 \mathrm{r}$. w westfalskim miasteczku Lennep (dzisiejsze Remscheid) i spędził pierwsze lata życia w Niemczech i Holandii. Jego ojciec Friedrich Conrad Röntgen byłniemieckim kupcem tekstylnym, natomiast matka Charlotte Constanze Frowein pochodziła z Holandii. Wilhelm byłich jedynym dzieckiem. Obecnie w Remscheid, w dawnym ratuszu, mieści się niemieckie Muzeum Röntgena, a w domu, w którym się urodził, znajduje się kolekcja jego książek i prac naukowych. Młody Wilhelm w Lennep

\section{Cartmel}

Grange-over-Sands

Cumbria LA11 6QG

United Kingdom 


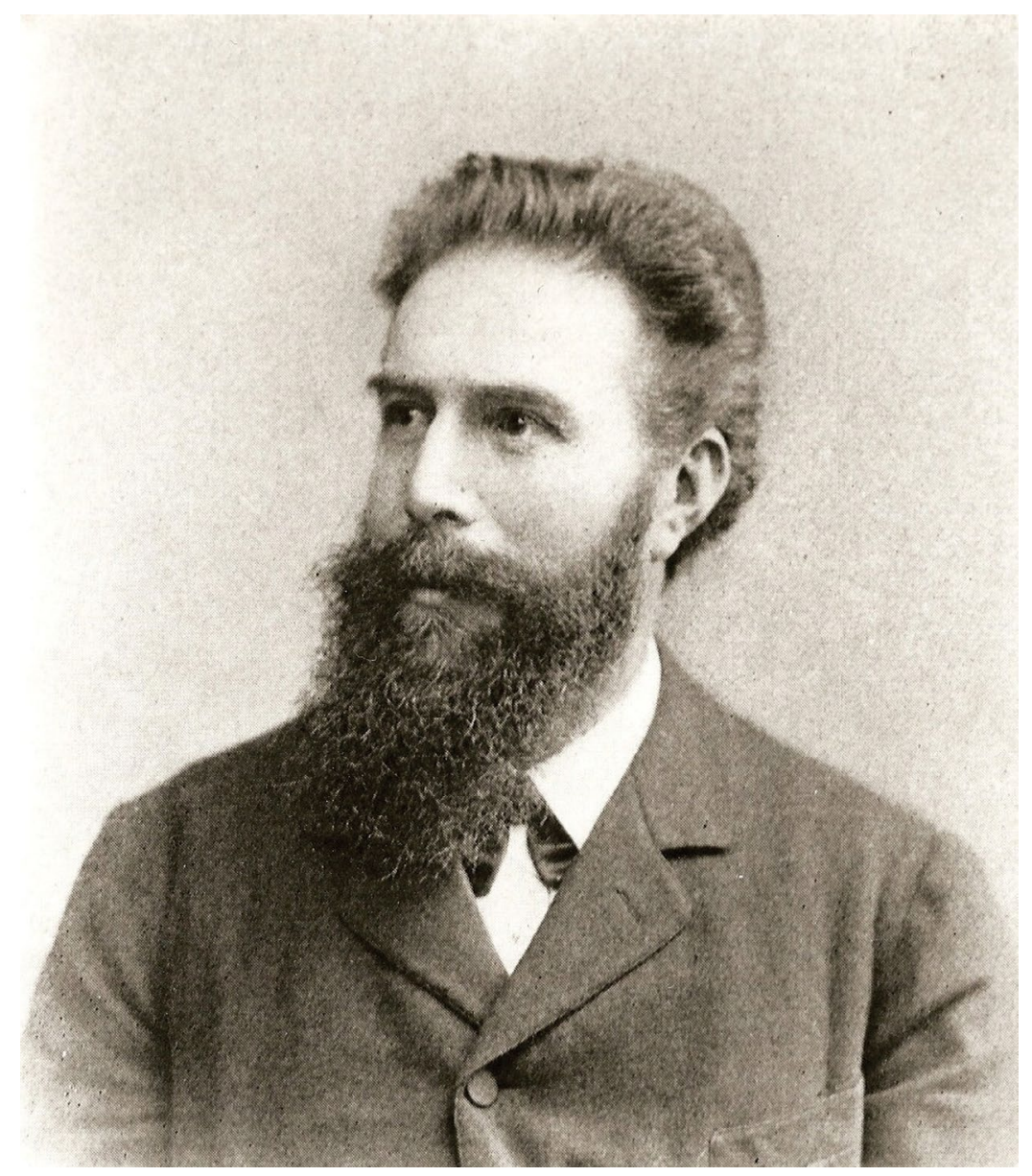

Rycina 1. Portret Röntgena z frontyspisu podręcznika na temat promieni X, opublikowanego w 1896 roku [1]

spędziłzaledwie pierwsze trzy lata życia. Następnie jego ojciec przeniósł się do Apeldoorn w Holandii, gdzie Röntgen otrzymał podstawowe wykształcenie. Później przeniósł się do Szkoły Technicznej w Utrechcie, a następnie na tamtejszy Uniwersytet.

W 1868 roku rozpoczął naukę na Politechnice w Zurychu jako student inżynierii mechanicznej, tam też uzyskał dyplom, a w 1869 r. obronił doktorat za rozprawę o gazach. Później odbywał studia podyplomowe na wydziałach fizyki na uniwersytetach w Würzburgu (1871), Strasburgu (1872 i 1876), Hohenheim (1875) i Giessen (1879). Po Giessen został powołany w 1888 roku na profesora fizyki na Uniwersytecie w Würzburgu, gdzie pozostawał do 1900 roku, kiedy to przeniósł się do Monachium, obejmując posadę szefa Uniwersyteckiego Instytutu Fizycznego (ryc. 1).

W roku 1894 Röntgen został rektorem Uniwersytetu w Würzburgu. Było to na rok przed odkryciem promieni $X$. Jako ciekawostkę warto przywołać słowa [2], które zacytował podczas swojego przemówienia inauguracyjnego, wypowiedziane przez jednego z wybitnych poprzedników na tym stanowisku — urodzonego w 1602 roku P. Athanasiusa Kirchera, profesora filozofii, teologa, jezuity, wykładowcy matematyki, hebrajskiego i syryjskiego:„Natura często pozwala na tworzenie niesamowitych cudów, które mają swoje źródła w najzwyk- lejszej obserwacji, jednak dostrzec mogą je tylko ci, którzy posiadają mądrośći przenikliwość badawczą, ale zarazem mają na uwadze doświadczenie - nauczyciela wszystkiego".

Odkrycie promieni X zaowocowało wieloma wyróżnieniami i spotkało się z licznymi dowodami uznania. Szczególne znaczenie miało przyznanie w roku 1901 pierwszej w historii nagrody Nobla w dziedzinie fizyki. Jednak Röntgen był osobą bardzo prywatną i unikał publicznych wystąpień. Na temat promieni rentgenowskich wygłosił tylko jeden publiczny wykład. W druku ukazały się zaledwie dwa przeprowadzone z nim wywiady i najprawdopodobniej były to jedyne wywiady, jakich kiedykolwiek udzielił. Röntgen zmarł w 1923 roku na raka jelit. Został pochowany w Giessen. Jego biograf Otto Glasser [2] napisał, że w późniejszym okresie Röntgen często mawiał, że oprócz czasu spędzonego w Würzburgu to właśnie w Giessen przeżył swoje najlepsze lata. Na nagrobku na starym cmentarzu w Giessen znajdują się też imiona jego rodziców oraz żony Berthy, która zmarła w 1919 roku.

\section{Odkrycie promieni X w 1895 roku}

W chwili odkrycia, w dniu 8 listopada 1895 r., Röntgen badał zjawisko powodowane przez przejście wyładowania elektrycznego z cewki indukcyjnej przez częściowo opróż- 
nioną szklaną rurkę. Rura została szczelnie pokryta czarnym papierem, a w pomieszczeniu panowała całkowita ciemność, jednak Röntgen zaobserwował, że w innym miejscu pokoju ekran papieru pokryty fluorescencyjnym materiałem, platynocyjankiem baru, został podświetlony.

Nie trzeba było długo czekać, żeby dowiedzieć się, że nie tylko czarny papier, lecz także inne przedmioty, takie jak drewniane deski, opasłe tomy książek czy kawałki blachy, także były penetrowane przez nowo odkryte promienie. Mówiąc słowami jego biografa Otto Glassera [2], odkrył, że „najdziwniejsze ze wszystkiego jest to, że podczas gdy ciało było bardzo przejrzyste, kości były nieprzejrzyste, a umieszczając rękę pod źródłem promieni, widział projekcję kości własnej żywej dłoni na ekranie. Zostało dokonane wielkie odkrycie".

Röntgen ogłosił swoje odkrycie dopiero siedem tygodni później, w grudniu 1895 r. [3], pod nagłówkiem: Eine Neue Art von Strahlen, lecz ani wówczas, ani w późniejszych dwóch pracach $[4,5]$ nie zamieścił żadnego z wykonanych przez siebie zdjęć. Te wysłał oddzielnie do swoich kolegów, profesorów fizyki, zarówno z Niemiec, jak i z innych krajów. Między innymi w styczniu 1896 roku wysłał dziewięć zdjęć rentgenowskich do Sir Arthura Schustera, profesora fizyki z Uniwersytetu w Manchesterze. Obecnie znajdują się one w archiwum Welcome Institute for the History of Medicine w Londynie (ryc. 2-5).

Glasser twierdzi [2], że Röntgen zwlekał z publikacją odkrycia przez siedem tygodni, ponieważ chciał mieć absolutną pewność co do swoich obserwacji. Przez cały ten czas nie opuszczał laboratorium. Przeniósł tam nawet swoje łóżko, a żona donosiła mu posiłki, aby mógł spokojnie pracować. Zdjęcie dłoni żony Röntgena, widoczne na rycinie 2, było pierwszym w historii zdjęciem rentgenowskim ludzkiego ciała. W tamtym czasie zaledwie raz wspomniał o swojej pracy jednemu z przyjaciół, niemieckiemu zoologowi Theodorowi Boveriemu, stwierdzając: „odkryłem coś bardzo interesującego, ale nie wiem, czy moje obserwacje są poprawne".

\section{Unikanie poparzeń popromiennych}

Röntgen nigdy nie cierpiał na poparzenia rąk wywołane promieniowaniem - w przeciwieństwie do wielu innych pionierów badających promienie rentgenowskie. Zapewne częściowo przyczyną tego był fakt, iż Röntgen pracował z promieniami X przez stosunkowo krótki czas; opublikował zaledwie trzy prace na temat promieni X [3-5], podczas gdy przez całą karierę zawodową napisał 55 rozpraw, w większości poświęconych innym zagadnieniom. Na potrzebę eksperymentów Röntgen skonstruował szafkę z blachy o wysokości około 2,1 metra i polu 1,2 metra kwadratowego, zbudowaną po to, jak to opisał w swojej drugiej publikacji [4], aby zapewnić warunki do eksperymentów z promieniami X nad rozładowywaniem naelektryzowanych ciał. $W$ ten

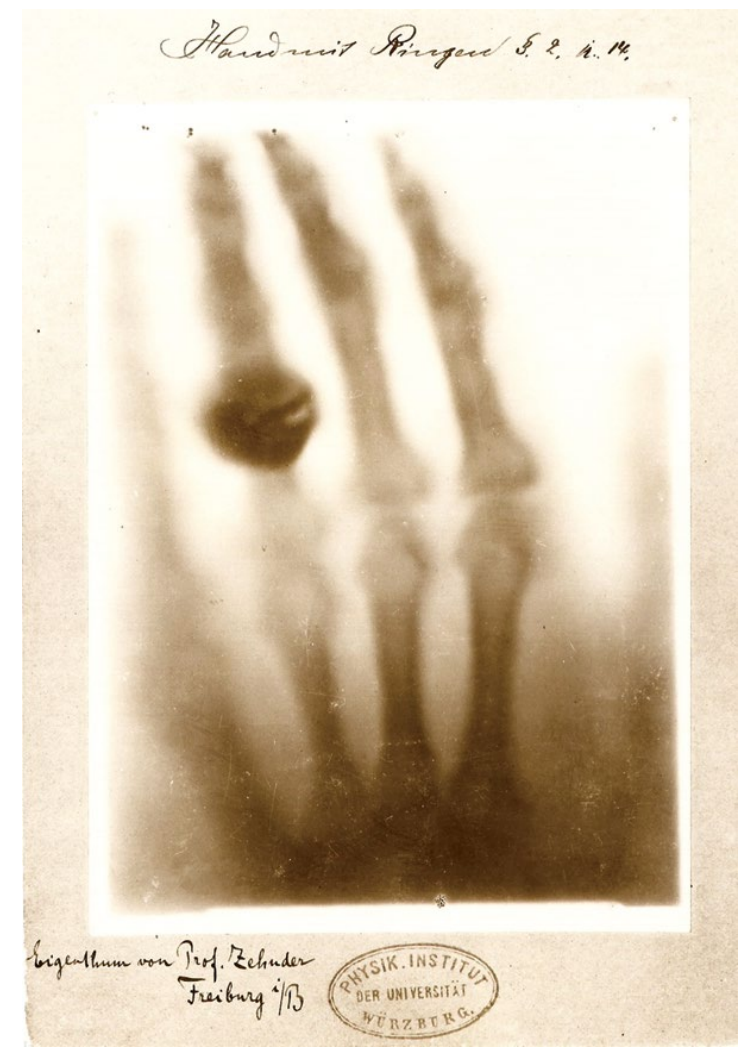

Rycina 2. Dłoń pani Röntgen. Kopia wysłana do szwajcarskiego fizyka Ludwiga Zehndera, byłego ucznia Röntgena

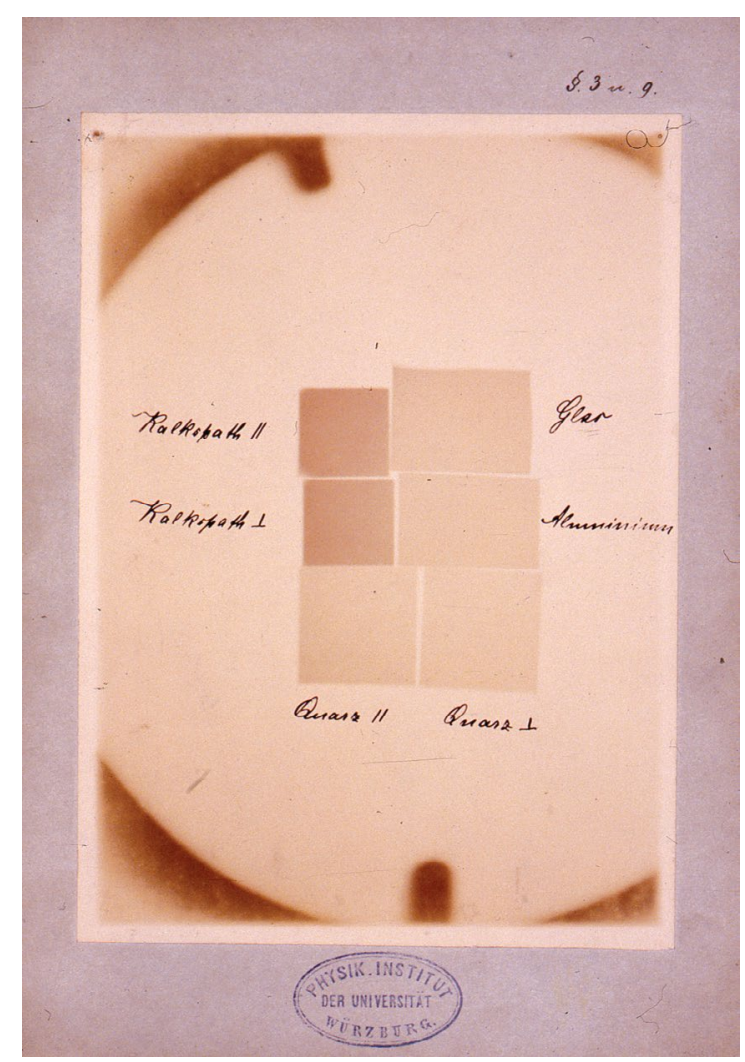

Rycina 3. Radiogram sześciu próbek o tej samej grubości, lecz wykonanych z różnych materiałów: szkła, aluminium, kalcytu i kwarcu 


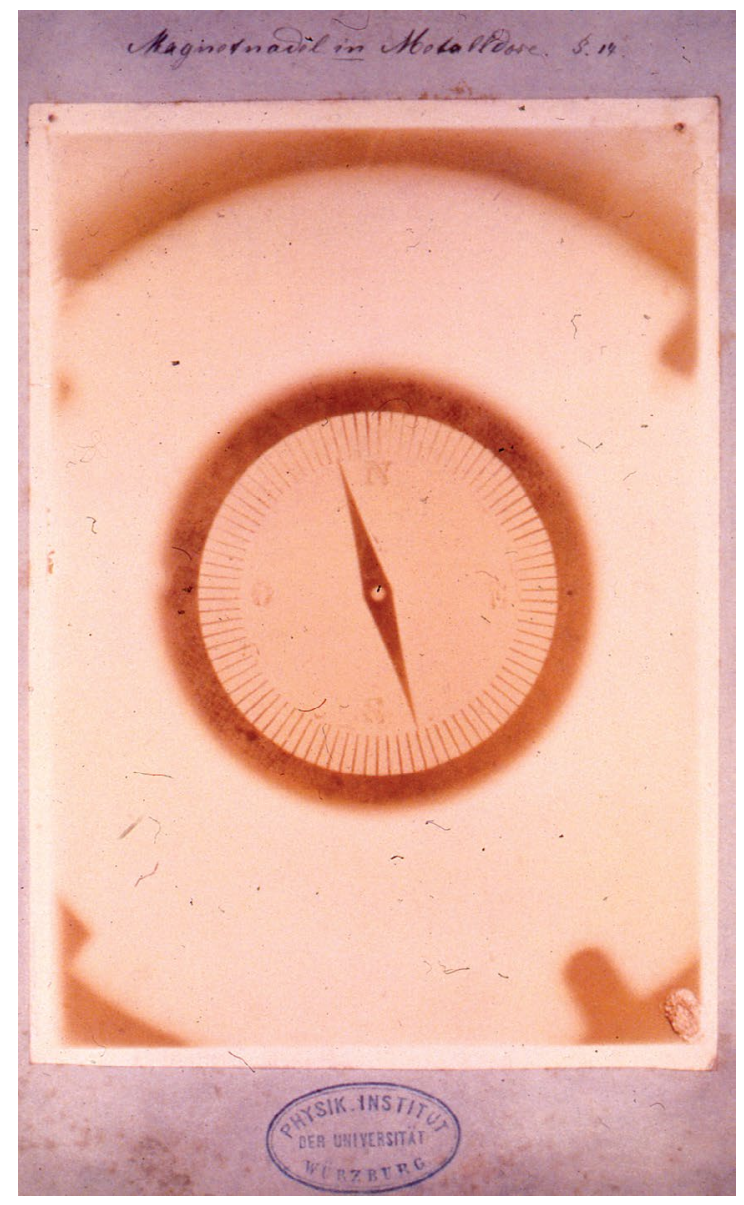

Rycina 4. Ołowiana klatka aparatu Röntgena. Ten radiograf był zapewne źródłem odkrycia, że promienie $\mathrm{X}$, w przeciwieństwie do promieni katodowych, nie są odbijane przez magnes

sposób uzyskał też bardzo skuteczną ciemnię, co odnotowano w kwietniu 1896 podczas wywiadu z Röntgenem przeprowadzonego przez HJW Dama dla amerykańskiego McClure's Magazine [6].

Z jednej strony szafki o cynkowych ścianach umieścił okrągłą blachę aluminiową o grubości $1 \mathrm{~mm}$ i średnicy $4 \mathrm{~cm}$, przez którą promienie rentgenowskie mogły przechodzić. Do wewnątrz można było wejść przez cynowe drzwi po przeciwległej stronie obudowy. Pomiędzy nim a lampą rentgenowską, na cynkowej ścianie, znajdowała się ołowiana płyta. W ten sposób, dzięki konieczności zachowania starannej konstrukcji ciemni, nieświadomie ochronił się przed szkodliwymi skutkami promieniowania.

\section{Wykład 23 stycznia 1896 roku w Würzburgu}

Od chwili ogłoszenia odkrycia przez cały 1896 rok odbywały się liczne pokazy i wykłady publiczne, jednak osobiście Röntgen tylko raz zaprezentował swoje dokonanie przed publicznością. Miało to miejsce 23 stycznia 1896 roku w Physikalisch-medizinischen Gessellschaft w Würzburgu. To właśnie wtedy wykonał zdjęcie dłoni anatoma Alberta

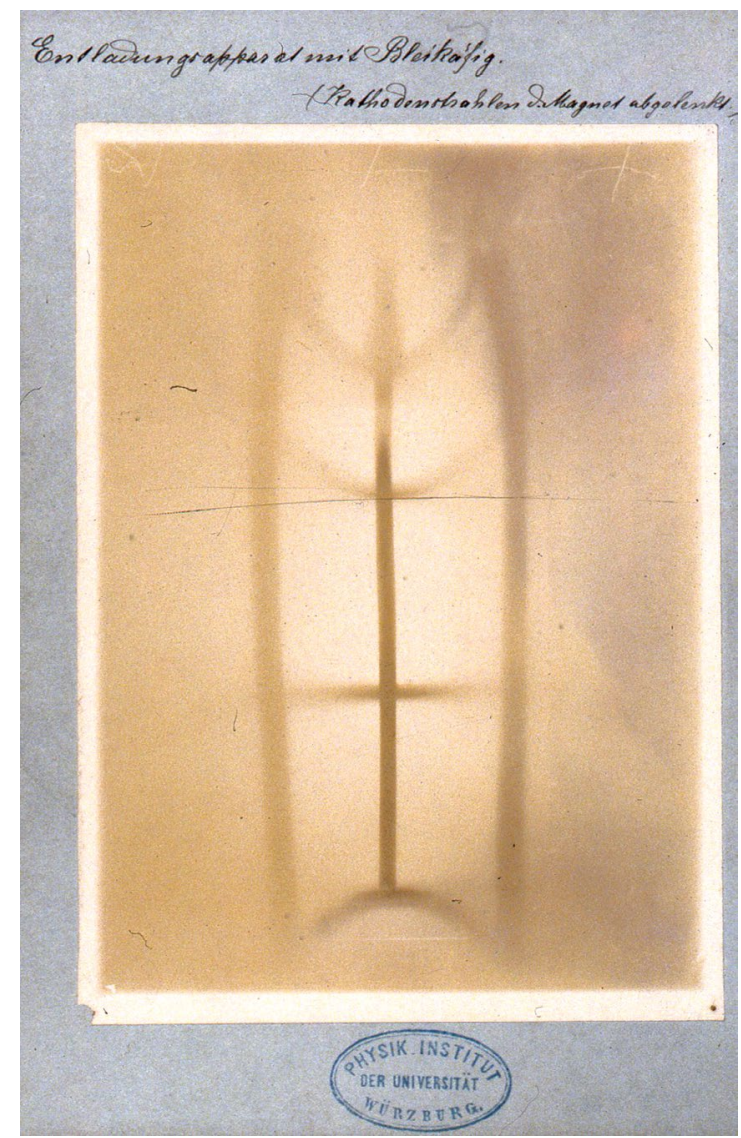

Rycina 5. Radiograf kompasu magnetycznego

von Köllikera, który zaproponował termin „promienie Röntgena" i wezwał obecnych na sali do wzniesienia trzech wiwatów na cześć Röntgena. Owacje trwały bez końca.

\section{Wywiad dla McClure's Magazine, 1896 rok}

W kwietniu 1896 roku w amerykańskim czasopiśmie McClure's Magazine pojawił się artykułzatytułowany The New Marvel in Photography — Nowy cud w fotografii [6]. Jego autorem był reporter HJW Dam. Biograf Röntgena Otto Glasser [2] stwierdzit, że był to pierwszy wiarygodny opis pracy Röntgena, i Dam poczynił wiele wnikliwych i wiarygodnych obserwacji. Dam jako pierwszy opisał plan Instytutu Fizycznego w Würzburgu, a następnie laboratorium Röntgena, porównując je z podobnymi laboratoriami w Stanach Zjednoczonych:„Lekcja w laboratorium była bardzo wymowna. W porównaniu z rozbudowanymi, kosztownymi i świetnie wyposażonymi pracowniami, powiedzmy na przykład na Uniwersytecie w Londynie lub na którymkolwiek z wielkich amerykańskich uniwersytetów, było do pewnego stopnia nagie i skromne. Milcząco dawało do zrozumienia, że w wielkim marszu nauki to geniusz człowieka, a nie doskonałość aparatury odkrywa nowe lądy na bezkresnym terytorium tego, co nieznane".

„Profesor Röntgen wszedł pospiesznie, jak przyjemny podmuch wiatru. Jest wysoki, szczupły i gibki, a cała jego 
postać wyraża entuzjazm i energię. Jego długie, ciemne i nastroszone nad czołem włosy sprawiają wrażenie naelektryzowanych jego własnym entuzjazmem. Ma pełny i głęboki głos i mówi szybko, ale ... nie ma wątpliwości, że woli wpatrywać się w rurę Crookesa, niż przyjmować gości. Szczególnie teraz, gdy odwiedzający okradają go z czasu, który tak wysoko sobie ceni. „A teraz - powiedział z uśmiechem i pewnym zniecierpliwieniem, gdy skończyłem zadawać mu kilka osobistych pytań, które go nieco poirytowały — przyszedłeś zobaczyć niewidzialne promienie”.,_Czy można zobaczyć to, co niewidzialne?" — „Nie gołym okiem, ale są wyniki. Chodź tutaj". Poprowadził mnie do kwadratowego pomieszczenia i wskazał na cewkę indukcyjną, z iskrą od 4" do 6", zasilaną przez prąd o natężeniu 20 amperów. Dwa przewody prowadziły z cewki przez otwarte drzwi do mniejszego pokoju po prawej stronie. W tym pokoju był mały stolik, na którym znajdowała się połączona z cewką rura Crookesa. Jednaknajbardziej rzucało się w oczy ogromne i tajemnicze blaszane pudło, wysokie na około 7 stóp i 4 stóp kwadratowych. Stało na końcu niczym ogromny pakunek, a jego bok znajdował się na oko o 5 cali od rury Crookesa".

Następnie Dam opisał ciemnię, o której już pisaliśmy w tej pracy. Został zaproszony do środka, aby siedząc na taborecie, obserwować skutki promieniowania $\mathrm{X}$ na kartce papieru zawierającej platynocyjanek baru. Początkowo Dam nie widział żadnego obrazu i napięcie lampy musiało zostać zwiększone, zanim ekran zaczął świecić. „Przez metalową płytę, papier, przeze mnie i blaszane pudło przelatywały widzialne promienie. Efekt był dziwny, ciekawy i niesamowity zarazem. Metalowa płyta wydawała się nie stawiać znaczącego odporu przelatującej sile, a światło było tak bogate i pełne, jak gdyby pomiędzy papierem a rurą nic się nie znajdowało".

„Umieść między nimi książkę" - powiedział profesor. Dam znalazł na półce ciężką książkę, grubą na 2 cale. Odnotował później, że nie zmieniło to natężenia światła. Następnie chciał się dowiedzieć, gdzie w pracowni wykonano pierwsze zdjęcia dłoni i zasugerował, aby sfotografować Röntgena dla potomności, ma się rozumieć: z czytelnikami Magazine McClure w pierwszej kolejności. Röntgen jednak odpowiedział, że nie ma czasu na zdjęcia.

Röntgen opisał historię odkrycia w następujący sposób: „Nie ma żadnej historii ... Od dawna interesowałem się problematyką promieni katodowych z rury próżniowej, jak te badane przez Hertza i Lenarda. Poszedłem śladem ich oraz innych badań z wielkim zainteresowaniem i postanowiłem, że gdy tylko znajdę czas, przeprowadzę badania na własną rękę. Znalazłem trochę czasu pod koniec października. Pracowałem już od kilku dni, kiedy odkryłem coś nowego". Zapytany przez Dama:, I co pan pomyślał?", Röntgen odpowiedział — „Ja nie myślałem, tylko prowadziłem badania".

(Podobną odpowiedź otrzymał Sir James Mackenzie Davidson w wywiadzie z lipca 1896 r., ale nagranym znacznie później, w 1914 roku, w apendyksie do książki autorstwa GWC Kaye z National Physical Laboratory w Wielkiej Brytanii) [7].

Wróćmy do rozmowy przeprowadzonej przez Dama. Röntgen kontynuował: „Sądziłem, że zjawisko to musi pochodzić z rury, jako że jego charakter wskazuje, że nie może pochodzić z żadnego innego źródła. Badałem więc dalej. W ciągu kilku minut nie było już wątpliwości. Promienie pochodziły z rury, która wywoływała zjawisko luminescencji na papierze. $Z$ powodzeniem podejmowałem kolejne próby z coraz większej odległości, nawet z 2 metrów. Na początku wyglądało to na nowy rodzaj niewidzialnego światła. To było zdecydowanie coś nowego, coś jeszcze nieodnotowanego".

Dam, zmierzając do konkluzji, na koniec rozmowy zapytał: „Co będzie w przyszłości?". Röntgen odpowiedział: "Nie jestem prorokiem i jestem przeciwny prorokowaniu. Usiłuję realizować moje badania i jak tylko wyniki będą zweryfikowane, podam je do publicznej wiadomości". Dam zapytał wówczas: „Czy uważa Pan, że promienie mogą być zmienione $w$ taki sposób, aby fotografować narządy wewnątrz ludzkiego ciała?".

W odpowiedzi Röntgen wyjął zdjęcie rentgenowskie pudełka ciężarków, powiedział: „Tutaj są już odpowiednie modyfikacje" - i wskazał różne stopnie zacienienia wytwarzanego przez aluminiowe, platynowe i mosiężne ciężarki, mosiężne zawiasy, a nawet metaliczny napis wytłoczony na wieku pudełka, który był ledwo wyczuwalny. Dam próbował ciągnąć temat, ale profesor Neuser już zapowiedział, że fotografowanie różnych narządów jest możliwe”.,_Zobaczymy to, co zobaczymy — odpowiedział Röntgen - Mamy dopiero początek, ulepszenia przyjdą z czasem".

Wkrótce potem Dam opuścił laboratorium Röntgena. Gdy ściskali sobie dłonie na pożegnanie, Röntgen powiedział: „Jest jeszcze wiele do zrobienia, a ja jestem zajęty, bardzo zajęty".

\section{Rozmowa Isenthala dla Röntgen Society z 1898 roku}

Adolf Isenthal był producentem aparatów elektrycznych i rentgenowskich. Był czołowym członkiem Towarzystwa Rentgenowskiego i współautorem podręcznika Practical Radiography. Autorem pierwszego wydania, które ukazało się 1896 roku jako pierwszy podręcznik o promieniach rentgenowskich, był Snowden Ward, który zawodowo zajmował się fotografią [9-11].

W dokumentach przekazanych British Institute of Radiology (do którego zostało wcielone Röntgen Society) [8] odnotowany jest fakt, że Röntgen był świadomy zagrożeń związanych z promieniowaniem, ale zbiór fotografii, do których się odnosił (zawierający fotografie uszkodzeń popromiennych) niestety zaginął. Został wspomniany jedynie przez Isenthala, u Glassera nie ma na jego temat żadnej wzmianki [2]. Jest wysoce prawdopodobne, że kolekcja 
została zniszczona w czasie II wojny światowej lub wraz z papierami Röntgena po jego śmierci w 1923 roku, na jego własną prośbę.

Isenthal opisał swoją rozmowę z Röntgenem następującymi słowami:„W kwietniu 1898 zostałem poproszony przez moich kolegów z Rady Towarzystwa Rentgenowskiego, aby — jeśli istnieje taka możliwość - przeprowadzić wywiad z Röntgenem na Uniwersytecie w Würzburgu. Uzyskawszy zgodę Röntgena, odwiedziłem go w jego laboratorium na Wydziale Fizyki, gdzie wyjaśnił mi konstrukcję aparatu, który doprowadził go do odkrycia nowego rodzaju promieniowania.

Röntgen był bardzo wysokim mężczyzną, po akademicku przygarbionym, o nieco chropowatej twarzy. Był surowy, ale uprzejmy i bardzo skromny, gdy opowiadał o swoich osiągnięciach. Czułem oczywiście specyficzny rodzaj podniecenia, wywołany przebywaniem w obecności tego światowej sławy naukowca. Byłem jeszcze bardziej podekscytowany, gdy powiedział, abym towarzyszył mu w jego prywatnej rezydencji, i zaproponował wspólną herbatę i rozmowę o tym »angielskim Towarzystwie Rentgenowskim«, które reprezentowałem. Nie mógłjednak przyjąć mojego na wpół oficjalnego zaproszenia do Anglii z powodu natłoku zobowiązań.

W trakcie naszej rozmowy zapytał mnie, czy w Anglii wiemy o biologicznych skutkach promieniowania rentgenowskiego, i z dużej teczki wyjął kilka bardzo wymownych fotografii uszkodzeń skóry, a następnie poprosił mnie, aby upowszechnić te fakty również u nas".

Isenthal zakończył swoje sprawozdanie w następujący sposób: „Po powrocie do Anglii zgłosiłem się do Towarzystwa Rentgenowskiego, jednak nie wywołałem dużego zainteresowania ostrzeżeniami Röntgena... Jeśli chodzi o mnie, to natychmiast podjąłem wszystkie możliwe środki ostrożności". Niemniej jednak, pomimo uwag Isenthala o braku zainteresowania, na posiedzeniu w dniu 1 marca 1898 Towarzystwo Rentgenowskie powołało komisję śledczą w sprawie rzekomego szkodliwego wpływu promieni Röntgena.

\section{Podziękowania}

Rycinę 2 wykorzystano dzięki uprzejmości Physik Institut der Universität Würzburg. Na zdjęciach tych widać rękopis
Röntgena. Ryciny 3-5 powielono dzięki uprzejmości Wellcome Institute for the History of Medicine. Zostały wysłane przez Röntgena Sir Arthurowi Schusterowi, profesorowi fizyki na Uniwersytecie w Manchesterze. Liczby w prawym górnym rogu niektórych zdjęć rentgenowskich odnoszq się do odpowiednich numerów paragrafów i sekcji w pierwszej publikacji Röntgena [3].

\section{Richard F. Mould MSc, PhD}

4, Town End Meadow

Cartmel

Grange-over-Sands

Cumbria LA11 6QG

United Kingdom

e-mail:manorroadsouthport@yahoo.co.uk

Otrzymano i przyjęto do druku: 3 października 2014 r.

\section{Piśmiennictwo}

1. Thompson EP. Roentgen Rays \& Phenomena of the Anode \& Cathode Principles, Applications \& Theories. New York: D van Nostrand, August 1896, \{Właściwie nie jest to podręcznik, a raczej bibliograficzne kompendium z ilustrowanymi podsumowaniami prac, jakie ukazały się na temat promieni rentgenowskich i elektryczności. Opisani autorzy to m.in. Faraday, Kelvin, Plücker, Hittorf, Hammer, Crookes, Hertz, Lenard, Edison, Tesla, Lodge \& Röntgen]

2. Glasser O. Wilhelm Conrad Röntgen.\& The Early History of the Roentgen Rays. London: John Bale, Sons \& Danielsson, 1933.

3. Röntgen WC. Über eine neue Art von Strahlen (Vorlaüfige Mittheilung) Sitzungsberichte derPhysikalishe-medizinischen Gesellschaft zu Würzburg 28 December 1895; 9: 132-41.

4. Röntgen WC. Eine neue Art von Strahlen (II. Mittheilung) Sitzungsberichte der Physikalishe-medizinischen Gesellschaft zu Würzburg 9 March 1896; 2: 11-7.

5. Röntgen WC. Weitere Beobachtungen über die Eigensschaten der X-Strahlen. Sitzungsberichte der königlich preussichen Akademie der Wissenschaften zu Berlin Gesamtsitzung vom 13 Mai 189720 May 1897; 26: 576-92. [Wydane w Wielkiej Brytanii w lutym 1899 w: The Archives of the Roentgen Ray].

6. Dam HJW. The new marvel in photography. McClure's Magazine April 1896; 6: 403. [Praca została przedrukowana w: Nitske RW. Wilhelm Conrad Röntgen Discoverer of the X-Ray. Tucson: University of Arizona Press, 1971, pp 126-37].

7. Kaye GWC. X-Rays: an Introduction to the Study of Röntgen Rays. London: Longmans Green 1914, appendix 1, p 218.

8. Isenthal AW. The Isenthal Bequest of historical photographs and papers deposited at the British Institute of Radiology. Accessed 1995.

9. Isenthal AW, Ward HS. Practical Radiography: a Handbook of the Applications of the X-rays, with Many Illustrations. $2^{\text {nd }}$ edn. London: Dawbarn \& Ward, 1898.

10. Isenthal AW, Ward HS. Practical Radiography: a Handbook for Physicians, Surgeons and Other Users of X-rays. $3^{\text {rd }}$ edn. London: Dawbarn \&Ward, 1901.

11. Ward HS. Practical Radiography: a Handbook of the Applications of the $X$-rays. $1^{\text {st }}$ edn. London: Dawbarn \& Ward, 1896. 